\title{
Investigating the Impact of Online Classes on Undergraduate Degree Completion
}

\author{
Sharon Wavle and Gamze Ozogul \\ Indiana University
}

\begin{abstract}
This study expands on current research that examines the impact of online courses on retention, degree completion, and student success. The researchers investigated the impact of online courses on degree completion by using existing graduation rate data, course enrollment data, and student grades for undergraduate students at a multicampus 4-year institution. The researchers aimed to provide advisors, faculty, and administrators with a better understanding of how online classes fit into an undergraduate student's program of study while completing their degrees within the desired time frame. The researchers additionally sought to understand the impact of taking online classes on degree completion while controlling for student demographic and academic factors (e.g., age, first-generation student status, socioeconomic status, SAT/ACT scores, and first semester GPA) and campus type (traditional flagship, urban research, and regional). Results indicated that, regardless of campus type, taking one or more online classes during their program of study increased undergraduate students' likelihood of successful degree completion. Lastly, to provide further insight, this study compared student performance in online and on-campus classes. Results for this comparison were mixed; slightly higher or slightly lower online course grades were obtained by students compared to face-to-face course grades, depending on type of campus.
\end{abstract}

Keywords: online classes, online learning, graduation rates, degree completion, course completion, retention, student success

Wavle, S., \& Ozogul, G. (2019). Investigating the impact of online classes on undergraduate degree completion. Online Learning, 23(4), 281-295. doi:10.24059/olj.v23i4.1558

\section{Investigating the Impact of Online Classes on Undergraduate Degree Completion}

Increasing demand for online learning is reflected in online enrollment growth rates that are over 10 times higher than the growth in overall higher education enrollments (Allen \& Seaman, 2010, 2013). Allen and Seaman (2015) documented that in every year since 2003 the number of students taking one or more online classes has grown at a rate greater than the growth rate for all students in higher education overall, with the number of online students often growing at rates of $20-28 \%$ per year. In fall 2015 , more than six million students, or $29.7 \%$ of all students involved in higher education, took one or more distance education courses, with the vast majority (83\%) of these students at the undergraduate level. The proportion of students taking one or more online class has risen steadily from under $10 \%$ in 2002 , to $25.9 \%$ in 2012, and $28.3 \%$ in 2014 . This growth in demand for online classes is happening even though the number of total students in higher education has declined slightly each year since 2012 (Allen \& Seaman, 2017). 
Despite this increasing student demand for online classes, Allen and Seaman (2015) report that only $28 \%$ of academic leaders feel that their faculty "fully accept the value and legitimacy of online education" (p. 12). Gutman (2012) describes concerns over online class quality as a barrier to faculty acceptance of online classes, stating that faculty are "skeptical about the effectiveness of courses delivered from a distance" and that many faculty still feel that online classes "are poor attempts to replace the teacher with technology" (p. 55). Taking this further, Grossman and Johnson (2015) found that business faculty were significantly less likely to accept transfer credit for classes taken in hybrid and online formats, despite equivalent grades and/or institution. Much of the faculty distrust of online education comes from the fact that online classes often have lower completion rates (Carr, 2000; Jaggars \& Xu, 2010; Xu \& Jaggars, 2011; Johnson et al., 2015; Shea \& Bidjerano, 2017; Hart et al., 2018), even though a recent study conducted by Wisneski, Ozogul, and Bichelmeyer (2017) reported no significant differences in student performance when undergraduate students were allowed to take prerequisite and postrequisite courses in a variety of online and on-campus combinations in their required course sequences.

\section{Review of Related Literature}

Since 2010 several studies have compared online and on-campus course completion rates and/or examined the impact of online classes on retention and degree completion rates. These studies were primarily conducted at the community college level, but a few studies have incorporated 4-year institutions as well. Table 1 below provides a brief summary of large-scale studies conducted from 2010 to 2018, providing the institution level at which they were conducted and the primary findings related to course completion and retention/degree completion as appropriate.

Table 1

Summary of Current Research: Online Courses, Course Completion, and Degree Completion

\begin{tabular}{llll}
\hline Study & Institution & \multicolumn{1}{c}{ Course completion } & \multicolumn{1}{c}{ Degree completion } \\
\hline $\begin{array}{l}\text { Jaggars \& Xu } \\
(2010)\end{array}$ & $\begin{array}{l}\text { Community } \\
\text { college }\end{array}$ & $\begin{array}{l}\text { Students more likely to fail or } \\
\text { withdraw from online course }\end{array}$ & $\begin{array}{l}\text { Taking online in early semesters } \\
\text { lowers retention and degree attainment }\end{array}$ \\
$\begin{array}{l}\text { Xu \& Jaggars } \\
(2011)\end{array}$ & $\begin{array}{l}\text { Community } \\
\text { college }\end{array}$ & $\begin{array}{l}\text { Students more likely to fail or } \\
\text { withdraw from online course }\end{array}$ & $\begin{array}{l}\text { Taking online in early semesters } \\
\text { decreases retention, and a high \% of } \\
\text { online slightly decreases completion }\end{array}$ \\
$\begin{array}{l}\text { Pontes \& } \\
\text { Pontes (2012) }\end{array}$ & Undergrad & $\begin{array}{l}\text { First-gen low-income students taking } \\
\text { online show increased progress toward } \\
\text { degree }\end{array}$ \\
$\begin{array}{l}\text { Xu \& Jaggars } \\
(2014)\end{array}$ & $\begin{array}{l}\text { Community } \\
\text { college }\end{array}$ & $\begin{array}{l}\text { All students performed lower in } \\
\text { online courses than face-to-face, } \\
\text { particularly males, younger } \\
\text { students, and Black students. }\end{array}$ & \\
$\begin{array}{l}\text { Shea \& } \\
\text { Bidjerano } \\
(2014)\end{array}$ & $\begin{array}{l}\text { Community } \\
\text { college }\end{array}$ & & $\begin{array}{l}\text { Early participation in online predicts } \\
\text { higher rates of degree attainment, even } \\
\text { for those at risk }\end{array}$ \\
\hline
\end{tabular}




\begin{tabular}{|c|c|c|c|}
\hline Study & Institution & Course completion & Degree completion \\
\hline $\begin{array}{l}\text { Johnson, } \\
\text { Cuellar Mejia, } \\
\& \text { Cook (2015) }\end{array}$ & $\begin{array}{l}\text { Community } \\
\text { college }\end{array}$ & $\begin{array}{l}\text { Pass rates in online courses lower } \\
\text { than traditional on campus }\end{array}$ & \\
\hline $\begin{array}{l}\text { Shea \& } \\
\text { Bidjerano } \\
(2016)\end{array}$ & $\begin{array}{l}\text { Community } \\
\text { college }\end{array}$ & & $\begin{array}{l}\text { Significantly more students engaged in } \\
\text { online attained a degree than those } \\
\text { who did not; women students graduate } \\
\text { more quickly when taking online }\end{array}$ \\
\hline $\begin{array}{l}\text { James, Swan, } \\
\text { \& Daston } \\
(2016)\end{array}$ & $\begin{array}{l}\text { 2- and 4-year } \\
\text { on-ground } \\
\text { and online }\end{array}$ & $\begin{array}{l}\text { Online courses do not impact } \\
\text { course completion rates }\end{array}$ & $\begin{array}{l}\text { Online courses did not lower retention } \\
\text { rates }\end{array}$ \\
\hline $\begin{array}{l}\text { Shea \& } \\
\text { Bidjerano } \\
(2017)\end{array}$ & $\begin{array}{l}\text { Community } \\
\text { college }\end{array}$ & $\begin{array}{l}\text { Online course GPAs lower } \\
\text { relative to on campus course } \\
\text { GPAs }\end{array}$ & $\begin{array}{l}\text { Students taking online and on campus } \\
\text { classes } 1.5 \text { times more likely to } \\
\text { complete degree; female, White, full- } \\
\text { time, older students more likely to take } \\
\text { online and on campus }\end{array}$ \\
\hline $\begin{array}{l}\text { Shea \& } \\
\text { Bidjerano } \\
(2018)\end{array}$ & $\begin{array}{l}\text { Community } \\
\text { college }\end{array}$ & & $\begin{array}{l}\text { Higher proportions of online classes } \\
\text { decreases degree completion (tipping } \\
\text { point }=40 \% \text { ) }\end{array}$ \\
\hline $\begin{array}{l}\text { Hart, } \\
\text { Friedmann, \& } \\
\text { Hill (2018) }\end{array}$ & $\begin{array}{l}\text { Community } \\
\text { college }\end{array}$ & $\begin{array}{l}\text { Outcomes in online courses } \\
\text { poorer than on campus }\end{array}$ & \\
\hline Ortagus (2018) & $\begin{array}{l}\text { 2- and 4-year } \\
\text { institutions }\end{array}$ & & $\begin{array}{l}\text { Positive relationship between taking } \\
\text { some online classes and long-term } \\
\text { outcomes, including earning a degree } \\
\text { or successful transfer }\end{array}$ \\
\hline
\end{tabular}

\section{Course Completion}

Seven of the 12 studies presented in Table 1 examined course grades and/or course completion in online classes compared to traditional on-campus classes. All but one of these studies found that student performance in online classes was lower than in on-campus courses. Jaggars and $\mathrm{Xu}$ (2010) studied 24,000 Virginia community college students and found that students were more likely to fail or withdraw from online courses. In a similar study of 51,000 students in the Washington State Community College System, Xu and Jaggars (2011) reached the same conclusion that students were more likely to withdraw from or fail their online classes. Xu and Jaggars (2014) extended their analysis of course completion to look at student subgroups, and found that in particular male students, younger students, and Black students suffered from the biggest performance gaps between online and on-campus courses. Johnson, Cuellar Mejia, and Cook (2015) studied online and traditional courses in the California Community College system and found higher rates of failing and incomplete grades in online courses, after adjusting for student type, college, subject, and term. Similarly, Shea and Bidjerano (2017) determined that in the community colleges of the State University of New York, the online GPAs of students were lower relative to the grades they earned in their on-campus classes. Hart, Friedmann, and Hill (2018) also studied the California Community College system and found that on average, student outcomes in online courses were poorer than those in on-campus courses, even when accounting for instructor differences. 
Of the studies presented in Table 1, only James, Swan, and Daston (2016) found that taking a course online did not impact course completion rates. Their study used student-level data available through the Predictive Analytics Reporting (PAR) Framework that included 2- and 4year colleges with a mix of institutions delivering instruction primarily online and primarily on campus.

\section{Degree Completion}

Nine of the 12 studies presented in Table 1 examined the impact of online classes on retention and/or degree completion and also showed mixed results. Both the Virginia Community College system study by Jaggars and Xu (2010) and the Washington State Community College system study by $\mathrm{Xu}$ and Jaggars (2011) reported that students who took online courses early in their academic career were slightly less likely to be retained than those who did not, and that those students with a high proportion of online course credits were less likely to complete their associate's degree. In contrast, Shea and Bidjerano (2014) found that early participation in online classes predicted higher rates of degree completion in community college students within the SUNY system, even though those students who were less likely to receive a degree were overrepresented in the national population of online students studied. They concluded that "even potentially less prepared students who participated in distance education early in their college careers were more likely to attain a degree than students who had not done so" (p. 110). Shea and Bidjerano (2014) also noted that students who were female, older, from larger families, and those who received higher amounts of financial assistance were more likely to take online courses.

Pontes and Pontes (2012) similarly studied a specific at-risk population and found that firstgeneration, low-income (FGLI) students who took online classes demonstrated better progress toward degree completion that those who did not take online classes. The authors noted that "FGLI students may be more likely to value the convenience of distance education classes, which allows them to stay enrolled in their program of study for the entire academic year" (Pontes \& Pontes, 2012, p. 6). Picciano, Seaman, and Allen (2010) supported this observation, suggesting that many students chose to enroll in online classes because the format affords a more flexible learning environment, allowing them to combine work and family obligations into their higher education plans.

Shea and Bidjerano (2016) examined national community college data from the National Center for Education Statistics, focusing on time-to-degree, dropout, and transfer rates for students taking at least one online course, compared to classroom-only students. Their results differed from prior studies at the state level (Xu \& Jaggars, 2011, and Jaggars \& Xu, 2010), finding that students who took online classes had higher rates of degree completion and earned their degree faster than those who took only campus classes, and that there were no significant differences in dropout or transfer rates among these students. Further, Shea and Bidjerano (2016) noted that the national data indicate that women take more online courses than men do and that "women graduate most quickly when they took at least some online classes" (Shea \& Bidjerano, 2016, p. 23).

James et al. (2016) also reported findings consistent with Shea and Bidjerano (2014, 2016) and contrary to the state-level community college studies by Xu and Jaggars (2011) and Jaggars and $\mathrm{Xu}$ (2010). They found that taking "some" online courses did not have a negative impact on student retention. An important distinction in James et al. (2016), however, was that the researchers grouped students into three categories: students with no online classes, students with all online classes, and students who took combinations of online and on-campus courses. After separating 
students into these groups, they found that students who took all of their courses online had lower retention rates, but students who took combinations of online and on-campus courses were retained at higher rates than students who took all of their courses on campus. No differences were observed in relation to gender or Pell Grant status.

Shea and Bidjerano (2017) continued to study community college students taking online classes, finding that students who took online classes had lower GPAs but were more likely to complete their degree than students who did not take online classes. They have described this as an "online paradox" in which students underperform at the course level yet overperform at the degree-completion level. Consistent with James et al. (2016), Shea and Bidjerano (2017) also found that students taking combinations of online and on-campus classes were more likely to complete their degree than students who took on-campus courses only. Students who took all of their classes online, however, were less likely to complete their degree than students who had combination online and on-campus schedules. In their most current study, Shea and Bidjerano (2018) examined the question further by exploring whether there is a "tipping point" at which students lose the benefits of taking online classes to enhance their chances of degree completion. The authors found that students who took $40 \%$ or more of their classes online start to see negative impacts on degree completion compared to their peers who took on-campus courses only.

Ortagus (2018) conducted a national study of both 2-year and 4-year students, examining the impact of taking either some or all online classes during a student's first year on long-term academic outcomes, including the likelihood of dropping out, likelihood of receiving a degree, and the likelihood of successful transfer. This study found that students from both the 2-year and 4year samples who enrolled in "some online courses" were less likely to drop out of college. Students in the 2-year sample who enrolled in some online courses were more likely to complete an associate's degree and were also more likely to successfully transfer to another 4-year institution than students who took only face-to-face courses.

\section{Additional Online Success Factors}

The above-described research studies focused on the impact of online class-taking behaviors on course and degree completion. There are other factors that can impact student success in online courses and programs, including student GPA, gender, age, ethnicity, first-generation status, and income status. For example, a few studies have found GPA to be a significant predictor of online success (Aragon \& Johnson, 2008; Harrell \& Bower, 2011; Xu \& Jaggars, 2013), finding that students with higher GPAs have higher rates of success in online courses. With respect to gender, Aragon and Johnson (2008) found a significant association between gender and course completion, finding that women had higher online course-completion rates than male students. Looking at ethnicity, Kaupp (2012) has noted that online instruction increases the achievement gap that already exists between Latino and White students. And, while Engle and Tinto (2008) have noted that FGLI students are four times more likely to leave college without a degree, Pontes and Pontes (2012) found that taking online classes decreased the likelihood that FGLI students would have an enrollment gap, increasing their progress toward their degree. In terms of age, Xu and Jaggars (2010) and Jaggars and Xu (2011) found that students aged 25 or higher were more likely to take online classes. Although these studies did not determine if age impacted performance in online classes specifically, McNeil, Long, and Ohland (2014) found that older students achieved both higher grades and higher graduation rates than their younger classmates in STEM coursework. 
In summary, much of the existing research on the differences between online and oncampus courses and their impact on degree completion has focused on state- and national-level community college data, with some newer studies beginning to look at transfer students and students working toward 4-year degrees. While early studies found negative impacts of taking online courses on retention, degree completion, and course completion, later studies have shown some positive results for taking some online courses. Thus, the purpose of this study is to examine the impact of taking online classes on degree-completion rates of first-time, full-time undergraduate students enrolled in 4-year bachelor's degrees at a multicampus university. This study will also investigate the additional factors identified above that have been shown to impact student retention in online classes and degree completion in both positive and negative ways.

\section{Research Questions}

To investigate the impact of taking online courses during undergraduate 4-year bachelor's degree programs at a multicampus university, the following two research questions were posed:

1. Does taking one or more online classes during a student's program of study increase the likelihood that a first-time, full-time undergraduate student will complete their degree on time?

2. Is there a difference in student performance, as measured by course grades, between online and on-campus classes?

Answers to these questions will help advisors, faculty, and administrators better understand how online classes fit into a student's program of study for the purpose of helping students complete their degrees within the desired time frame. The results of this study may be of benefit to administrators and faculty looking to improve degree-completion rates to help meet federal and state performance metrics and goals. This study may also inform decisions about departmental course offerings as well as the distribution of online versus on-campus courses offered each semester. Understanding the overarching role of online classes may also help to improve faculty perceptions of online courses and their willingness to design and teach online classes, as well as recommend them to their students as an option when needed.

\section{Method}

\section{Participants}

Existing student graduation-rate data from 12,840 students who entered in the fall 2010 first-time, full-time cohort at a large multicampus public university in the Midwest served as the data set for the study. At the time this study was undertaken, using the data from the fall 2010 cohort provided the necessary 6-year window that allowed for determination of whether the student completed the bachelor's degree within 6 years, or $150 \%$ of program length (the standard metric used for graduation-rate analysis at the university). Inclusion of student demographic and academic performance data allowed for analysis of the results while controlling for specific factors identified in the literature as having possible impacts on degree completion, including age, gender, ethnicity, income status, first-generation student status, first semester GPA, composite SAT/ACT scores, and number of credit hours taken online.

Data for this study were obtained from official university graduation-rate study census files for all students enrolled in the fall 2010 full-time, first-time undergraduate cohort. All students in 
the selected cohort were included in the data set for the data analysis. The graduation-rate study census files contained the following attributes for each student:

- Campus type: Classifies students into three primary campus types based on campus size, student demographics, and student academic attributes: traditional flagship campus, urban research campus, and regional campus.

- Residency: Identifies the student as an in-state resident or nonresident student.

- Pell/Stafford: Indicates whether the student was a recipient of Pell Grant or Stafford Loan benefits as a proxy for low-income indication.

- Gender: The self-identified gender of the student at the time of program enrollment.

- Underrepresented minority: Based on university definitions, a dichotomous variable created to indicate whether the student identified as Hispanic, Black/African American, Pacific Islander, or Two or More Races on the student application for admission.

- First-generation status: Indicates whether the student is a first-generation college student.

- Age: The age of the student at the time of program enrollment.

- SAT/ACT composite score: Student composite score as calculated from submitted SAT and ACT scores from the student application for admission.

- First semester GPA: Student GPA in their first academic term of their program of study.

- Degree completion flag: Indicates whether the student completed their degree within $150 \%$ of the expected program length.

Official university census enrollment and grade data were also used to create a flag indicating whether a student had taken one or more online classes during their program of study. This data was also used to calculate each students' online and on-campus GPA as described in the data analysis section below.

\section{Data Analysis}

The fall 2010 graduation-rate study cohort files were retrieved from the University Institutional Research and Reporting website and filtered to include only first-time, full-time undergraduate students. All students that were marked as deceased or withdrawn for military duty were excluded from the data set. Each first-time, full-time undergraduate student included in the study population was queried in the university enrollment and course grade snapshot files to determine the number of online and on-campus credit hours each student took during their undergraduate career. For each course taken, grades in the form of quality points (e.g., A = 4.0, B $=3.0$, etc.) were also accumulated to calculate student GPA values (total credit hours $\div$ total quality points) for online and on-campus courses. Consistent with the Integrated Postsecondary Education Data System (IPEDS) definitions, courses categorized as "online" included those that use asynchronous and/or synchronous technologies to bridge the distance between the student and instructor when they are separated by a physical distance $76 \%$ or more of the class time (NCES, 2016). Classes not meeting these criteria were categorized as "on campus" for comparison. Online and on-campus credit hours and quality points for each student were mapped back to the graduation-rate cohort files using Excel VLOOKUP functions.

The fall 2010 data were summarized by comparing graduation rates for students who took one or more online classes during their undergraduate career to those who did not take any online classes. Descriptive analyses were conducted for each of the three campus types - traditional 
flagship campus, urban research campus, and regional campus-consistent with traditional demographic groups at the university. Later, ANOVA tests were performed to determine the differences between students at each campus type in terms of the number of online class credit hours taken online, age, SAT score, first semester GPA, online course GPA, and on-campus course GPA.

In order to answer Research Question 1, investigating the impact of online classes on student degree-completion rates, variables typically associated with completion as mentioned in prior research findings were identified and controlled for in a logistic regression model. The variables considered as potential factors that could impact degree completion included residency status, Pell/Stafford status (as an indicator of socioeconomic status), gender, underrepresented minority status, first-generation student status, age at time of enrollment, SAT/ACT composite score, first semester GPA, and earning at least one credit in an online class.

In order to answer Research Question 2, whether online courses had an impact on student performance as measured by course grades, paired samples $t$-tests were conducted. These $t$-tests were conducted for each campus type to account for differences in student demographics and preparation.

\section{Results}

\section{Overall Demographic Analysis}

Table 2 shows the results of the overall descriptive analysis for the fall 2010 cohort data used for this study. The demographic characteristics in Table 2 were presented for all students and were also broken out by campus type: traditional flagship campus, urban research campus, and regional campus.

Table 2

Fall 2010 First-Time, Full-Time Cohort Demographics by Campus Type

\begin{tabular}{|c|c|c|c|c|}
\hline & All campuses & Flagship & Urban & Regional \\
\hline All students & 12,840 & 6,935 & 2,647 & 3,258 \\
\hline Resident students & $10,087(79 \%)$ & $4,377(63 \%)$ & $2,509(95 \%)$ & $3,201(98 \%)$ \\
\hline Pell/Stafford recipient & $6,554(51 \%)$ & $2,654(38 \%)$ & $1,727(65 \%)$ & $2,173(67 \%)$ \\
\hline Female & $7,196(56 \%)$ & $3,636(52 \%)$ & $1,587(60 \%)$ & $1,973(60 \%)$ \\
\hline Underrepresented minority & $1,942(15 \%)$ & $870(13 \%)$ & $467(18 \%)$ & $605(19 \%)$ \\
\hline First generation & $3,915(31 \%)$ & $1,317(19 \%)$ & $1,103(42 \%)$ & $1,495(46 \%)$ \\
\hline Average age & 18.9 & 18.6 & 18.9 & 19.6 \\
\hline Average SAT/ACT composite score & 1100 & 1199 & 1013 & 944 \\
\hline Average first semester GPA & 2.84 & 3.06 & 2.78 & 2.44 \\
\hline $\begin{array}{l}\text { Students taking one or more online } \\
\text { class }\end{array}$ & $5,174(40 \%)$ & $2,009(29 \%)$ & $1,683(64 \%)$ & $1,482(46 \%)$ \\
\hline Students completing in 6 years & $7,557(59 \%)$ & $5,328(77 \%)$ & $1,240(47 \%)$ & $989(30 \%)$ \\
\hline $\begin{array}{l}\text { Completion: students taking one or } \\
\text { more online }\end{array}$ & $69 \%$ & $85 \%$ & $65 \%$ & $52 \%$ \\
\hline Completion: students with no online & $52 \%$ & $74 \%$ & $16 \%$ & $12 \%$ \\
\hline
\end{tabular}


One-way analysis of variance (ANOVA) tests were conducted on all variables displayed in Table 2 to determine whether the percentages on the categorical variables (residency, Pell/Stafford recipient, gender, underrepresented minority, first generation) or averages for the continuous variables (age, SAT/ACT score, first semester GPA) varied significantly between the three campus types. The analysis revealed that all of the variables were significantly different $(p<$ $.01)$ at the univariate level between the traditional flagship, urban research, and regional campus types. Follow-up Bonferroni corrections were conducted, and these differences were confirmed, with additional clarifications between campus type for gender, underrepresented minority, and Pell/Stafford recipient. For these three variables, there was a significant difference $(p<.01)$ between the flagship campus and the urban and regional campuses, but the urban campus and regional campuses did not vary significantly on these two variables. There were significantly more Pell/Stafford recipients, women students, and underrepresented minority students at the urban and regional campuses compared to the traditional flagship campus. The number of Pell/Stafford recipients, women students, and underrepresented minority students was not significantly different between the urban and regional campuses. The three campus types also varied significantly in the percentages of students taking one or more online class, as well the number of students in the cohort who completed their degree within $150 \%$ of the program length.

To summarize the campus-type differences, students at the traditional flagship campus were more likely to be nonresident, younger, higher income students (as indicated by Pell/Stafford recipient status), also with higher SAT scores and higher first semester GPAs than students at the urban research campus or regional campuses. The traditional flagship students were less likely to be first-generation students, were less likely to take one or more online classes during their program of study, and were more likely to complete their degree on time. In contrast, students at the regional campuses were most likely to be resident, older, first-generation students with lower SAT/ACT composite scores and lower first semester GPAs, and were less likely to complete their degree on time.

Table 3 below displays a demographic comparison of the fall 2010 cohort. The table presents the frequencies of students who did not take any online courses during their academic program compared to those who did take one or more online courses. Similar to the campus-type breakdown, one-way ANOVA tests were conducted on all demographic variables to determine whether the percentages on the categorical variables (residency, Pell/Stafford recipient, gender, underrepresented minority, first generation) or averages for the continuous variables (age, SAT/ACT score, first semester GPA) varied significantly between students who took online classes and those who did not. All of the variables presented in Table 3 were significantly different between students taking one or more online classes and those taking no online classes $(p<.01)$ except for student age and underrepresented minority status. Students in the fall 2010 cohort who took one or more online classes during their academic program were more likely to be in-state residents, Pell/Stafford recipients, female, first-generation students with lower SAT/ACT composite scores and higher first semester GPAs. 
Table 3

Fall 2010 First-Time, Full-Time Cohort Demographics by One or More Online Class Variable

\begin{tabular}{lrrr}
\hline & All students & No online classes & $\begin{array}{r}\text { One or more } \\
\text { online class }\end{array}$ \\
\hline All students & 12,840 & 7,666 & 5,174 \\
Resident students & $10,087(79 \%)$ & $5,614(73 \%)$ & $4,473(87 \%)$ \\
Pell/Stafford recipient & $6,554(51 \%)$ & $3,717(49 \%)$ & $2,837(55 \%)$ \\
Female & $7,196(56 \%)$ & $4,038(53 \%)$ & $3,158(61 \%)$ \\
Underrepresented minority & $1,942(15 \%)$ & $1,155(15 \%)$ & $787(15 \%)$ \\
First generation & $3,915(31 \%)$ & $2,101(27 \%)$ & $1,814(35 \%)$ \\
Average age & 18.9 & 18.9 & 18.9 \\
Average SAT/ACT composite score & 1100 & 1125 & 1063 \\
Average first semester GPA & 2.84 & 2.75 & 2.98 \\
Students completing degree in 6 years & $7,525(59 \%)$ & $3,971(52 \%)$ & $3,554(69 \%)$ \\
\hline
\end{tabular}

Research Question 1: Does taking one or more online classes during a student's program of study increase the likelihood that a first-time, full-time undergraduate student will complete their degree on time? To determine whether taking an online class had an impact on earning a degree for the fall 2010 cohort, a logistic regression analysis was conducted for each campus type to predict degree completion using "taking one or more online class" as a predictor. Other predictors included in the model were Pell/Stafford status, gender, underrepresented minority status, first-generation student status, age at time of enrollment, SAT/ACT composite score, and first semester GPA. Residency was removed from the final results because it did not improve the model due to the high percentages of resident students at the urban research and regional campuses (95\% and $98 \%$, respectively). The regression models with the variables summarized in Table 4 correctly predicted student degree completion at the rate of $81 \%$ for the flagship campus, $76 \%$ for the urban campus, and $78 \%$ for the regional campuses. The power of explanation of the models as measured by Nagelkerke's $R^{2}$ for each campus type were 0.279 (flagship), 0.474 (urban), and 0.435 (regional), indicating that the model was the best fit for the urban campus. 
Table 4

Variables in the Logistic Regression Models With Significance and Odds Ratio

\begin{tabular}{lcccccc}
\hline & \multicolumn{2}{c}{ Flagship } & \multicolumn{2}{c}{ Urban } & \multicolumn{2}{c}{ Regionals } \\
\hline Variable & Sig. & $\begin{array}{c}\text { Odds } \\
\text { ratio }\end{array}$ & Sig. & $\begin{array}{c}\text { Odds } \\
\text { ratio }\end{array}$ & Sig. & $\begin{array}{c}\text { Odds } \\
\text { ratio }\end{array}$ \\
\hline Age at time of enrollment & .204 & 0.927 & .001 & 0.827 & .048 & 0.921 \\
SAT/ACT composite score & .354 & 1.000 & .025 & 1.001 & .007 & 1.001 \\
First semester GPA & .000 & 3.935 & .000 & 3.516 & .000 & 3.219 \\
$\begin{array}{l}\text { Earned at least one online class } \\
\text { credit }\end{array}$ & .000 & 2.667 & .000 & 8.060 & .000 & 6.185 \\
Pell/Stafford recipient & .000 & 0.696 & .047 & 0.799 & .138 & 0.853 \\
Gender (female) & .052 & 1.144 & .015 & 0.765 & .771 & 0.969 \\
First-generation student & .001 & 0.746 & .000 & 0.613 & .003 & 0.736 \\
Underrepresented minority & .977 & 0.822 & .852 & 1.027 & .000 & 0.553 \\
\hline
\end{tabular}

Research Question 2: Is there a difference in student performance, as measured by course grades, between online and on-campus classes? Nondirectional dependent $t$-tests were carried out to examine whether the student GPAs in their online classes were different from GPAs in their on-campus classes. For all students at all campuses, the results indicated a significant difference between online and on-campus GPAs, with lower GPAs in on-campus courses $(M=$ $2.79, S D=0.65)$ than GPAs in online courses $(M=2.84, S D=1.19), t(5167)=-4.24, p<.05$, CI $(-0.08,-0.02)=.95$. Following this initial analysis, grades were examined by campus type, with additional $t$-tests showing significant differences in online and on-campus GPAs for traditional flagship, urban, and regional campus students. For the flagship campus, on-campus GPAs $(M=$ $2.90, S D=0.51)$ were lower than online GPAs $(M=3.04, S D=1.11), t(2008)=-6.35, p<.05$, CI $(-0.18,-0.10)=.95$. The result for the urban campus also showed that on-campus GPAs $(M=2.78$, $S D=.71)$ were lower than online GPAs $(M=2.87, S D=1.14), t(1677)=-4.5, p<.05$, CI $(-0.13$, $-0.05)=.95$. The results for the regional campuses, however, indicated that on-campus GPAs $(M$ $=2.66, S D=0.71)$ were higher than online GPAs $(M=2.56, S D=1.29), t(1480)=3.80, p<.05$, CI $(0.05,0.15)=.95$. These results are summarized in Table 5 .

Table 5

Mean Online and On-Campus GPAs (Range $=0.0$ to 4.0) by Campus Type

\section{Online}

\section{On-campus}

\begin{tabular}{lcccc} 
Campus type & $\boldsymbol{M}$ & $\boldsymbol{S D}$ & $\boldsymbol{M}$ & $\boldsymbol{S D}$ \\
\hline All campuses & 2.84 & 1.19 & 2.79 & 0.65 \\
Traditional flagship & 3.04 & 1.11 & 2.90 & 0.51 \\
Urban & 2.87 & 1.14 & 2.78 & 0.71 \\
Regional & 2.56 & 1.29 & 2.66 & 0.71 \\
\hline
\end{tabular}




\section{Discussion}

The purpose of this study was to investigate whether online classes have an impact on degree completion for first-time, full-time undergraduate students. Within the cohort studied at this multicampus university, taking online classes indicated a significant positive impact on student degree completion at all three campus types, with the biggest effect on students at the urban research and regional campuses, where graduation rates overall are typically lower than the traditional flagship campus. As presented in Table 4, students who took an online class at the flagship campus were 2.7 times more likely to complete, students at the regional campuses were 6.2 times more likely to complete, and students at the urban campus were 8.1 times more likely to complete their degree within 6 years.

In the urban research campus and regional campus regression models, earning at least one online class credit was the variable that increased the likelihood of degree completion the most, with first semester GPA as the second most important variable. These variables were reversed at the flagship campus, with first semester GPA as the variable with greatest impact followed by taking one or more online classes. These findings are consistent with studies by Shea and Bidjerano (2016), James et al. (2016), and Shea and Bidjerano (2017) that focused on community college students and found positive impacts on degree completion for these less traditional students.

With respect to the impact on student grades when students took one or more online classes during their undergraduate program of study, the differences between student GPAs in online classes and student GPAs in on-campus classes showed mixed results. At the flagship and urban campuses, students had slightly higher GPAs in online classes. At the regional campuses, online GPAs were slightly lower than on-campus GPAs, which may support the results of studies on community college students that show lower pass rates for online students (Xu \& Jaggars, 2011; Jaggars \& Xu, 2010; Johnson et al., 2015; Shea \& Bidjerano, 2017; Hart et al., 2018). While statistically significant, the differences found in this study could be considered practically insignificant, since the difference between the means of the online and on-campus GPAs was 0.10 or less at all three campus types. This would support James et al. (2016), who found no impact on course completion among 2- and 4-year students. Concerns that some faculty have regarding student performance or quality in online classes may be alleviated by these results that show student performance overall between online and on-campus classes is almost equivalent.

Similar to Shea and Bidjerano (2014), the students in this study who took online classes during their degree were more likely to be women and more likely to be financial aid recipients, an indication of lower socioeconomic status, than those who did not take online classes. The students taking online classes also had significantly lower SAT/ACT composite scores than those who did not take online classes, yet the students who took online classes graduated at higher rates than those who did not. This supports Shea and Bidjerano (2014), who observed that at the national level, distance education students were somewhat less prepared for college, yet they still had a greater chance of graduating than their peers who did not take online classes. In this study, students at the campuses with the lowest graduation rates - the urban and regional campuses - showed the most benefit from taking online classes with regard to degree completion. This is an important finding given that state-performance funding models often use metrics such as overall degree completion, on-time degree completion, and/or degree completion for at-risk students as a fundamental component. 
The authors of this current study agree with Shea and Bidjerano (2014) and Ortagus (2017) that online learning may provide greater access to certain populations of students, particularly those with work responsibilities, family obligations, or even physical/mobility impairments that make coming to a traditional campus class difficult. This points out an important limitation of the current study, however. While the regression model incorporated student academic and demographic factors into the analysis, student behavioral factors, student motivation, and external factors, such as employment and family responsibilities, were not measured or accounted for in this study. While student work schedules, family commitments, athletic schedules, or even other class obligations may make online learning an imperative for some students, it is also very possible that online classes simply have a greater appeal for some students. Jaggars (2014) asked students to identify their reasons for taking online courses, receiving the expected key reasons of flexibility and convenience, but "a handful of students preferred the learning environment of online learning" (Jaggars, 2014, p. 28). If today's students prefer to consume other services (e.g., music, books, and games) digitally, it follows that they may also have a preference for consuming education in a digital format. Understanding today's students' demands and motivations for choosing online education may help guide the development of online programs and courses as well as inform the types of student services and support needed to help students succeed in their online classes and complete their degrees timely.

While this study had the advantage of large sample sizes from three different types of campuses, the study population was from a single multicampus university and included only firsttime, full-time students. Additional research should examine if and how transfer students consume online education to complete their degrees. This study also did not consider the student program of study or the subject areas of the courses taken online, which could have an impact on student grades and completion rates. Some studies have considered the timing of when students take their online classes with mixed results (Jaggars \& Xu, 2010; Xu \& Jaggars, 2011; Shea \& Bidjerano, 2014). It would be helpful for advisors to know, for example, if taking online classes in the freshman year was more problematic than if the student waits until later. It is possible that taking online classes in the summer has a particularly important impact. The current study did not consider the timing of when students took their online classes, and also did not distinguish whether students took some of their classes online versus all of their classes online. Another potential area of research is to consider the percentage of online classes taken, as studied by Shea and Bidjerano (2017). As they suggest, perhaps there is a "tipping point" at which students are negatively impacted by taking too many of their classes online. If so, what are the implications for students who are enrolled in a fully online program, and how can colleges support fully online students to improve their levels of completion?

The results of this study showed that for undergraduate first-time, full-time students at a 4year institution, online classes may play an important role in supporting degree completion. There are specific populations, such as women and lower income students, for whom online classes play a bigger role than they do for their male and higher income counterparts. Further research designed to understand the populations that online education is helping and why it helps is important for administrators and faculty alike. It is possible that the growth in online learning can be attributed not only to the fact that online classes facilitate degree completion for populations most at risk of not completing their degrees, for a variety of reasons, but also that online learning is becoming a preferred choice among today's learners who are digital natives more comfortable learning in the online space. 


\section{References}

Allen, I. E., \& Seaman, J. (2008, November). Staying the course: Online education in the United States, 2008. Needham, MA: The Sloan Consortium.

Allen, I. E., \& Seaman, J. (2015, February). Grade level: Tracking online education in the United States, 2014. Babson Survey Research Group and Quahog Research Group, LLC.

Allen, I. E., \& Seaman, J. (2017, May). Digital learning compass: Distance education enrollment report 2017. Babson Survey Research Group.

Aragon, S. R., \& Johnson, E. S. (2008). Factors influencing completion and noncompletion of community college online courses. The American Journal of Distance Education, 22(3), 146-158. doi:10.1080/08923640802239962

Carr, S. (2000). As distance education comes of age, the challenge is keeping the students. The Chronicle of Higher Education, 23, 39-46.

Engle, J., \& Tinto, V. (2008). Moving beyond access: College success for low-income, first generation students. Pell Institute for the Study of Opportunity in Higher Education. Retrieved from http://www.eric.ed.gov/PDFS/ED504448.pdf

Grossman, A. M., \& Johnson, L. R. (2015, March). Faculty perceptions of online accounting coursework. American Journal of Business Education, 8(2), 95-106.

Gutman, D. (2012). Six barriers causing educators to resist teaching online, and how institutions can break them. Distance Education, 9(3), 51-56.

Harrell, I. L., \& Bower, B. L. (2011). Student characteristics that predict persistence in community college online courses. American Journal of Distance Education, 25(3), 178191.

Hart, M. D. C., Friedmann, E., \& Hill, M. (2016). Online course-taking and student outcomes in California community colleges. Education Finance and Policy, 13, 1-58.

Jaggars, S. S. (2014). Choosing between online and face-to-face courses: Community college student voices. American Journal of Distance Education, 28, 27-38.

Jaggars, S. S., \& Xu, D. (2010). Online learning in the Virginia community college system. New York: Community College Research Center, Teachers College, Columbia University.

James, S., Swan, K., \& Daston, C. (2016). Retention, progression and the taking of online courses. Online Learning, 20(2), 75-96.

Kaupp, R. (2012). Online penalty: The impact of online instruction on the Latino-White achievement gap. Journal of Applied Research in the Community College, 19(2), 8-16.

McNeil, J., Long, R., \& Ohland, M. W. (2014). Getting better with age: Older students achieve higher grades and graduation rates. 2014 IEEE Frontiers in Education Conference (FIE) Proceedings, Frontiers in Education Conference (FIE), 2014 IEEE. 1, 1-5.

National Center for Educational Statistics (2016). 2016-17 Survey materials: Glossary. IPEDS 2016-2017 data collection system. Retrieved from https://surveys.nces.ed.gov/ipeds/VisGlossaryAll.aspx 
Ortagus, J. C. (2017). From the periphery to prominence: An examination of the changing profile of online students in higher education. Internet and Higher Education, 32, 47-57.

Ortagus, J. C. (2018). National evidence of the impact of first-year online enrollment on postsecondary students' long-term academic outcomes. Research in Higher Education, 59(8), 1035-1058.

Picciano, A., Seaman, J., \& Allen, I. E. (2010). Educational transformation through online learning: To be or not to be. Journal of Asynchronous Learning Networks, 14(4), 17-35.

Pontes, M., \& Pontes, N. (2012). Distance education enrollment is associated with greater academic progress among first generation low-income undergraduate students in the US in 2008. Online Journal of Distance Learning Administration, 15(1).

Shea, P., \& Bidjerano, T. (2014). Does online learning impede degree completion? A national study of community college students. Computers \& Education, 75, 103-111.

Shea, P., \& Bidjerano, T. (2016). A national study of differences between online and classroomonly community college students in time to first associate degree attainment, transfer, and dropout. Online Learning, 20(3), 14-25.

Shea, P., \& Bidjerano, T. (2017). Online learning in the 30 community colleges of the State University of New York: Differences in outcomes between classroom and online coursework. In Johnston (Ed.), Proceedings of EdMedia: World Conference on Educational Media and Technology 2017 (pp. 1192-1198). Washington, DC: Association for the Advancement of Computing in Education (AACE). Retrieved from https://www.learntechlib.org/p/178436/

Shea, P., \& Bidjerano, T. (2018). Online course enrollment in community college and degree completion: The tipping point. International Review of Research in Open and Distributed Learning, 19(2), 282-293.

Wisneski, J., Ozogul, G., \& Bichelmeyer, B. (2017). Investigating the impact of learning environments on undergraduate students' academic performance in a prerequisite and post-requisite course sequence. The Internet and Higher Education, 32, 1-10.

Xu, D., \& Jaggars, S. S. (2011). Online and hybrid course enrollment and performance in Washington State community and technical colleges. (CCRC Working Paper No. 31). New York, NY: Columbia University, Teachers College, Community College Research Center.

Xu, D., \& Jaggars, S. S. (2013). The impact of online learning on students' course outcomes: Evidence from a large community and technical college system. Economics of Education Review, 37, 46-57.

Xu, D., \& Jaggars, S. S. (2014). Performance gaps between online and face-to-face courses: Differences across types of students and academic subject areas. The Journal of Higher Education, 85(5), 633-659. 